\title{
Formulation of Ketoprofen Transdermal Solid Dispersion Patch as an Analgesic and Anti-Inflammatory
}

\section{Fitri Yani*, Anayanti Arianto, Rosidah Noersal}

Department of Pharmaceuticals, Faculty of Pharmacy, Universitas Sumatera Utara, Medan, Indonesia.

\begin{abstract}
A B S T R A C T
Objective: to formulate transdermal patches of ketoprofen solid dispersions, determine the effect of propylene glycol on the rate of release of ketoprofen transdermal solid dispersion patches to know the optimum transdermal patch form of a solid dispersion of ketoprofen could provided better analgesic and antiinflammatory effects compared to the trademark ketoprofen gel (Kaltrofen $\mathbb{R})$.

Design: this research was conducted using a transdermal experiment of dense solid dispersion patches of ketoprofen with variations in the amount of propylene glycol F1 (10\%), F2 (20\%) and F3(30\%), physicochemical characteristics (organoleptic, fiber, weight uniformity, folding enhancement and development), diffraction patterns (XRD), incompatibility patterns (FTIR), in vitro penetration testing. -vitro, evaluation of analgesic and anti-inflammatory activity.

Interventions: the intervened variable were the in vitro penetration testing. In-vitro, evaluation of analgesic and antiinflammatory effect of ketoprofen transdermal solid dispersion patch.

Main outcome measures: the main measurement in this study were physicochemical characteristics (organoleptic, fiber, weight uniformity, folding enhancement and development), diffraction patterns (XRD), incompatibility patterns (FTIR), in vitro penetration testing. -vitro, evaluation of analgesic and anti-inflammatory activity.

Results: transdermal patches of ketoprofen solid dispersion patches produce white, odorless preparations that have a flat surface, thickness between $0.0242 \pm 0.0002$ to $0.0269 \pm 0.0003$, weight uniformity $321.50 \pm 0.78$ to $381.54 \pm 0.60$, folding resistance between $375 \pm 0.58$ to $443 \pm 1.53$, all formulas already meet the requirements of physicochemical characteristics. F3 ketoprofen transdermal solid dispersion patch had a highest penetration degree and provide better analgesic effects compared to the trademark ketoprofen gel (Kaltrofen $\left.{ }^{\circledR}\right)$, and there were significant differences between groups $(p>0.05)$.

Conclusion: it can be concluded that the use of 30\% propylene glycol in F3 ketoprofen transdermal solid dispersion patch affects the rate of drug release and had a better anti-inflammatory effect compared to the trademark ketoprofen gel (Kaltrofen ${ }^{\circledR}$ ).
\end{abstract}

Keywords: Ketoprofen, Transdermal solid dispersion patch, Analgetic, Anti-inflammatory.

A R T I C L E I N F O: Received 26 April 2020; Review Completed 05 May 2020; Accepted 09 May 2020; Available online 15 June. 2020

Cite this article as:

Yani F*, Arianto A, Noersal R, Formulation of Ketoprofen Transdermal Solid Dispersion Patch as an Analgesic and AntiInflammatory,Asian Journal of Pharmaceutical Research and Development. 2020; 8(3):49-56 DOI: http://dx.doi.org/10.22270/ajprd.v8i3.760

*Address for Correspondence:

Fitri Yani, Department of Pharmaceuticals, Faculty of Pharmacy, Universitas Sumatera Utara, Medan, Indonesia.

\section{INTRODUCTION}

$\mathrm{K}$ etoprofen is one of the non-steroidal antiinflammatory drugs (NSAIDs) which replaces the enzyme cyclooxygenase 1 (COX-1) which inhibits prostaglandin synthesis ${ }^{1}$. Ketoprofen is commonly used to reduce pain, inflammation and stiffness caused by several conditions such as osteoarthritis, rheumatoid arthritis, ankylosing spondylitis, or stomach cramps associated with menstruation ${ }^{2}$. Repeated administration of ketoprofen orally causes several side effects including gastric ulcer, duodenal ulcer, and gastrointestinal bleeding ${ }^{3}$. To overcome the side effects of ketoprofen orally, the administration of ketoprofen is given transdermally. Today, the market has produced ketoprofen in gel preparations, one example is Kaltrofen ${ }^{\circledR}$ gel $2.5 \%$, but gel preparations still have some disadvantages, namely in daily use it is very easily erased by clothing and sweat, so its use must be repeated. To overcome these problems, ketoprofen preparations are made in the form of transdermal patches so that they are easy to use, the concentration of drugs in blood is constant and, most importantly, can improve the bioavailability of drugs 
because first pass metabolism through the liver can be avoided $^{4,5}$.

Transdermal patch is a system of drug delivery through the skin to give certain doses and distribute drugs to systemic circulation by using adhesives ${ }^{6}$. The patch ensures that the drug is distributed at a controlled release rate. The drug particles must first be dissolved to form molecules that can diffuse through the polymer, then the drug will penetrate through the skin. Based on the formulation method, patches are divided into two groups namely membrane controlled systems and matrix controlled systems ${ }^{7}$. In this study, matrix type patches are used because they have several advantages, namely if there is damage to the polymer, no leakage occurs so that the drug is not released in large quantities, elegant dosage forms, smaller and thinner, making the process easy, fast, and lower costs ${ }^{8}$.

One of important component in transdermal patch preparations is polymer. The polymer functions to control the release of drugs in the preparation. The right combination of hydrophilic and hydrophobic polymers can deliver drugs in a controlled manner. The use of hydrophilic polymers alone will cause the drug to be released quickly from the preparation, while the use of hydrophobic polymers alone can slow the rate of drug release because a strong barrier will form which causes the drug to be trapped in the preparation so that the drug is difficult to release 9 . In a study 10 about the optimization of polyvinylpyrrolidone and carbopol on a pyroxycam solid dispersion patch, it was shown that a mixture of ethyl cellulose (EC), hydroxypropyl methylcellulose (HPMC) and polyvinylpyrrolidone (PVP) patches could release the drug continuously for 8 hours. Ethylcellulose (EC) is a lipophilic polymer that has been widely used in controlled loose preparations. Ethyl cellulose is a polymer that has no expanding characteristics but has a strong barrier film so that it will produce a good patch preparation and serves to regulate the speed of drug release from the polymer with a matrix system ${ }^{11}$.

Polyvinylpyrrolidone (PVP) is a hydrophilic polymer that can increase drug release due to pore formation and prevent crystallization of the drug in the matrix ${ }^{12}$. Hydroxypropyl methylcellulose (HPMC) is a hydrophilic polysaccharide polymer. The choice of HPMC is because HPMC is easily hydrated by water, so that it expands and accelerates drug release from its base ${ }^{13}$.

The weakness of ketoprofen lies in its solubility. Ketoprofen is practically insoluble in water ${ }^{14}$, so we need a method to increase the solubility of ketoprofen. Methods that can be used to improve the solubility of ketoprofen are made in the form of solid dispersions. There are three techniques in making solid dispersions, namely melting, dissolving and dissolving. Ketoprofen solid dispersions are prepared by the dissolution method, the advantage being that thermal decomposition of the drug or carrier can be prevented because it uses the low temperature required for the evaporation of organic solvents ${ }^{15}$. Further research on the effect of HPMC and propylene glycol on the transdermal transport of propranolol $\mathrm{HCl}$ in a matrix patch preparation using factorial design methods, obtained the results that the higher levels of propylene glycol will further increase drug penetration.

Based on the description above, the researchers were interested in examining the effect of propylene glycol polymers in ketoprofen solid dispersion patches on penetration rates as well as analgesic and antiinflammatory effects.

\section{MATERIALS AND METHODS}

This research was conducted using a transdermal experiment of dense solid dispersion patches of ketoprofen with variations in the amount of propylene glycol, physicochemical characteristics (organoleptic, fiber, weight uniformity, folding enhancement and development), diffraction patterns (XRD), incompatibility patterns (FTIR), in vitro penetration testing. -vitro, evaluation of analgesic and anti-inflammatory activity

\section{Research sites}

The study was conducted from February 2019 to June 2019 in the Cosmetology Laboratory of the Faculty of Pharmacy, the Physical Pharmacy Laboratory of the Faculty of Pharmacy, and the Research Laboratory of the Faculty of Pharmacy, Universitas Sumatra Utara, Medan.

\section{Material, chemical reagents and tools}

The tools used in this study are glassware, calipers, analytical balance, magnetic stirrer, magnetic bar, oven, $\mathrm{pH}$ meter (Hanna), petri dish, desiccator, micrometer screw (Delta), diffusion cell franz (cell donor and cell receptor), UV spectrophotometer (Shimadzu), X-ray diffraction (XRD) (Rigaku), Spectra Fourier-Transform IR (FTIR) (Shimadzu IR Prestige-2), animal scales, razors, scalpels, plantar test infrared (Ugo Basile), digital pletismometer (Ugo Basile). The materials used in this study are Ketoprofen (Fagron chemical industries, Australian), Kaltrofen® gel (Kalbe Farma), Ethyl cellulose, Hydroxypropyl methylcellulose, Polyvinylpirolidone, Propylene glycol, Chloroform (Merck), Ethanol, distilled water, Ethyl cellulose, Hydroxypropyl methylcellulose, Polyvinylpirolidone, Propylene glycol, Chloroform (Merck), Ethanol, distilled water, Ethyl cellulose, Hydroxypropyl methylcellulose, Polyvinylpirolidone, Propylene glycol, Chloroform (Merck), Ethanol, distilled water, Ethyl cellulose $\mathrm{NaOH}$ ) (Merck), potassium dihydrogen phosphate $\left(\mathrm{KH}_{2} \mathrm{PO}_{4}\right)$ (Merck), sodium chloride (Merck), Potassium Bromide (KBr) (Merck), $\lambda$-carrageenan (Sigma).

\section{Preparations of ketoprofen calibration curve}

Standard solutions II were pipette $0.1 ; 0.2 ; 0.4 ; 0.6 ; 0.8$; $0.8 ; 1.4 ; 1.4 ; 1.6 ; 1.6,1.8,2,2$ and $2.4 \mathrm{ml}$ then put into a $10 \mathrm{ml}$ flask and added phosphate buffer solution $\mathrm{pH} 7.4$ to the mark line, shaken until homogeneous. The absorption was measured with a UV spectrophotometer at a wavelength of $260.0 \mathrm{~nm}$, until the concentration of 1-24 $\mu \mathrm{g} / \mathrm{ml}$ is obtained.

\section{Preparation of ketoprofen solid dispersion patch transdermal preparations}

Transdermal patch formulation of ketoprofen solid dispersion consist of 3 formulas that could be seen on table 1 . 
Table: 1. Ketoprofen solid dispersion patch transdermal formula

\begin{tabular}{|l|l|l|l|}
\hline \multirow{2}{*}{ Composition } & Formula & \multicolumn{2}{l|}{} \\
\cline { 2 - 4 } & F1 & F2 & F3 \\
\hline Ketoprofen & $0.54 \mathrm{mg}$ & $0.54 \mathrm{mg}$ & $0.54 \mathrm{mg}$ \\
\hline Ethyl Cellulose & $150 \mathrm{mg}$ & $150 \mathrm{mg}$ & $150 \mathrm{mg}$ \\
\hline HPMC & $100 \mathrm{mg}$ & $100 \mathrm{mg}$ & $100 \mathrm{mg}$ \\
\hline PVP & $50 \mathrm{mg}$ & $50 \mathrm{mg}$ & $50 \mathrm{mg}$ \\
\hline Propylene Glycol & $30 \mathrm{mg}$ & $60 \mathrm{mg}$ & $90 \mathrm{mg}$ \\
\hline Total & $330.54 \mathrm{mg}$ & $360.54 \mathrm{mg}$ & $390.54 \mathrm{mg}$ \\
\hline
\end{tabular}

The ketoprofen patch was made by the dissolution method, the active substance ketoprofen was dissolved in a mixture of chloroform $(2.5 \mathrm{ml})$ and ethanol $(2.5 \mathrm{ml})$ plus EC polymer, HPMC and PVP slowly stirred with magnetic stirrer until homogeneous, add propylene glycol to be stirred again using magnetic stirrer until homogeneous. The resulting solution was poured in a mold that had been coated with aluminum foil. The solvent was allowed to evaporate at $40{ }^{\circ} \mathrm{C}$ for 24 hours, the resulting film was transferred to plaster ${ }^{16}$. The evaluation of physicochemical characteristics included organoleptic, thickness, uniformity of weights, folding resistance and development.

\section{X-ray Diffraction (XRD)}

X-ray diffraction patterns of ketoprofen powder, each polymer, and mixtures were recorded on an X-ray diffraction system using a $\mathrm{Cu}$ radiation source, a voltage of $40 \mathrm{KV}$ and a current of $30 \mathrm{~mA}$. Observations were made at a scanning speed of 0.050 per second ${ }^{17}$.

\section{Spectra Fourier-Transform IR}

Spectra Fourier-Transform IR was obtained using FT-IR spectrophotometer. Ketoprofen samples, each polymer and polymer-drug mixture, were mixed evenly with potassium bromide at a weight ratio of $1: 5$ (sample: potassium bromide). Potassium bromide plates were prepared by pressing powder at a pressure of 5 tons for 5 minutes in a hydraulic press. Then the percent transmittance measured at wave numbers $400-4000 \mathrm{~cm}-1$ 17 .

\section{In vitro penetration test}

In this study, the skin of male rabbits with a weight ranging from $1.5-2 \mathrm{~kg}$. Hair on the abdomen was shaved carefully using a razor. Shaving was done on the day before taking the skin to condition according to the environment. Rabbits were killed by anesthetized using chloroform and the skin of the abdomen was cutted with surgical scissors. Cleaned the attached fat, washed with distilled water, wrapped in aluminum foil, and stored immediately in the freezer until the experiment is carried out. When the skin is going to be used, the skin is soaked with $0.9 \% \mathrm{NaCl}$ solution for 24 hours ${ }^{18}$.

Penetration tests were carried out using a vertical type Franz diffusion cell. The donor compartment was placed in the transdermal patch of ketoprofen. The donor compartment and receptor compartment separator membrane was rabbit skin. The membrane was placed between the donor compartment and the receptor compartment with the dermis side facing the receptor compartment. The receptor compartment contains a $\mathrm{pH}$ of phosphate buffer of $19 \mathrm{ml}$ and is stirred with a magnetic stirrer at $37 \pm 0.5^{\circ} \mathrm{C}{ }^{19}$. Observations were carried out for 10 hours and samples were taken at the 5th, 10th, 15th, 30 th, 45th, 60th, 120th, 180th, 240th, 300th, 360th, 420th, 420th, 480th, 540th and 600th every $1 \mathrm{ml}$ sample taking was done by adding the solution buffer phosphate $\mathrm{pH}$ of 7.4 as much as $1 \mathrm{ml}$. The sample was put into a $10 \mathrm{ml}$ flask and a phosphate buffer solution was added to $\mathrm{pH} 7.4$ to the mark line. Absorption is measured at the maximum absorption wavelength and determined by the amount of drug that is penetrated.

\section{Evaluation of analgesic effect with the plantar method}

The adapted rat was divided into 3 groups and each group consisted of 8 rat. Animal test groups were as follows:

Group I : Transdermal patch without medication (control)

Group II : Trademark ketoprofen gel (Kaltrofen ${ }^{\circledR}$ )

Group III: Transdermal patch of ketoprofen (F3) solid dispersion

The principle of this experiment was to observe the reaction time that occurs from rat placed in a plantar container and heat-induced from an infrared movable generator. Induction of heat was done on the soles of rat feet and the response of experimental animals could be either pulling or licking feet.

\section{Evaluation of anti-inflammatory effect by paw edema} method

The part of the rat's left leg segment marked with a marker, then measuring its volume by dipping it in the triton water column on the pletismometer until the marked limit on the rat's leg segment, recorded as the initial leg volume (V0), transdermal patch affixed to the back of the rat, after 10 minutes each rat was given an induction of edible carrageenan $1 \%$ solution by $0.05 \mathrm{ml}$ intraplantar on the dorsal part of the left leg. The left leg volume of the rat was measured again at intervals of 5 , $10,15,30,45,60,120,180,240,300,360,420,480,540$ and 600 minutes.

The percentage of inflammation ( $\% \mathrm{R})$ can be calculated using the following formula:

$$
\% \mathrm{R}=\frac{\mathrm{Vt}-\mathrm{Vo}}{\mathrm{Vo}} \mathrm{x} 100 \%
$$

Note: $\% \mathrm{R}=$ percentage of inflammation, $\mathrm{Vo}=$ initial foot volume, $\mathrm{Vt}=$ foot edema volume at the t-time 
The percentage of inflammation inhibition (\% R) can be calculated using the following formula:

$$
\% \mathrm{IR}=\frac{a-b}{a} \times 100 \%
$$

Note: $\%$ IR = percentage of inflammation inhibition, $\mathrm{a}=$ percentage of inflammation average of the control treatment group, $\mathrm{b}=$ average percentage inflammation of the test group

\section{Skin irritation test}

Skin irritation test was performed on mice that had been tested for analgesics and anti-inflammatory. After using transdermal patches of solid dispersion of ketoprofen for 10 hours on the back of the rat, then released and erythema examination on the skin. Erythema is determined depending on the color changes caused on the skin of mice. If there is no change in color then there is no erythema, if it turns to pink, mild erythema occurs, if it turns to pink, it occurs immediately erythema, if it turns to dim pink, serious erythema occurs ${ }^{20}$.

\section{Statistic analysis}

The research data were analyzed using the IBM SPSS Statistics 21 program and analyzed using the One Way ANOVA method to determine the average difference between groups. If there are differences, it is done by using the Post Hoc Tukey HSD test to see real differences between treatments.

\section{RESULT AND DISCUSSION}

Results of Evaluation Transdermal Characteristics of Ketoprofen Solid Dispersion Patches

The results of evaluation transdermal characteristics of ketoprofen solid dispersion patches rations could be seen in Table 2.

Table: 2. Results of evaluation transdermal characteristics of ketoprofen solid dispersion patches.

\begin{tabular}{|c|c|}
\hline Evaluations & Result \\
\hline $\begin{array}{l}\text { Organoleptic: } \\
\text { - Color } \\
\text { - Smell } \\
\text { - Consistency and Surface conditions }\end{array}$ & $\begin{array}{l}\text { White } \\
\text { Odorless } \\
\text { F1: Dry and flat } \\
\text { F2: Dry and flat } \\
\text { F3: A little wet and } \\
\text { flat }\end{array}$ \\
\hline $\begin{array}{l}\text { Thickness } \\
(\text { Average }(\mathrm{cm}) \pm \mathrm{SD})\end{array}$ & $\begin{array}{l}F 1: 0.0242 \pm 0.0002 \\
F 2: 0.0245 \pm 0.0001 \\
F 3: 0.0269 \pm 0.0003\end{array}$ \\
\hline $\begin{array}{l}\text { Uniformity of weights } \\
\text { (Average }(\mathrm{mg}) \pm \mathrm{SD})\end{array}$ & $\begin{array}{l}\text { F1: } 321.50 \pm 0.78 \\
F 2: 352.14 \pm 0.56 \\
F 3: 381.54 \pm 0.60\end{array}$ \\
\hline $\begin{array}{l}\text { Folding resistance } \\
(\text { Average } \pm \mathrm{SD})\end{array}$ & $\begin{array}{l}F 1: 375 \pm 0.58 \\
F 2: 397 \pm 1.53 \\
F 3: 443 \pm 1.53\end{array}$ \\
\hline
\end{tabular}

The result showed that formulas 1 and 2 produced a dry and flat surface condition, while in formula 3 a patch with a slightly wet consistency and a flat surface was obtained. This is because the formula 3 uses propylene glycol more than formula 1 and 2 . The use of propylene glycol with a concentration of $30 \%$ can cause the patch surface to be slightly wet. Propylene glycol is hygroscopic which can bind water vapor in the environment, so that it can increase humidity ${ }^{21}$.

Test results above showed that the thickness of the patch in this test ranges from $0.0240-0.0272 \mathrm{~cm}$. The test results of each formula showed that F3> F2> F1. Formula 3 had the highest thickness value compared to formulas 1 and 2 because in formula 3 it used more propylene glycol which is $30 \%$. Propylene glycol is hygroscopic, which can bind water vapor in the environment, so that the patch is thicker ${ }^{21}$.

The weight of all formulas did not reach the amount of material from the basic formula used. Lack of preparation weight due to material left behind during the mixing and pouring process into the mold. The variation in weight of the preparation was also strongly influenced by the physical and chemical properties of the polymer used.

All patch formulas had a fold resistance of more than 300 times, not broken and still have good surface conditions. The results of the folding resistance of all formulas were in accordance with the requirements, the polymer was not damaged by being folded up to 300 times ${ }^{22}$. All formulas contain HPMC polymers, as it was known that HPMC could be used as a binder or binding agent, the presence of a strong bond on HPMC could produce patches with great folding resistance ${ }^{21}$.

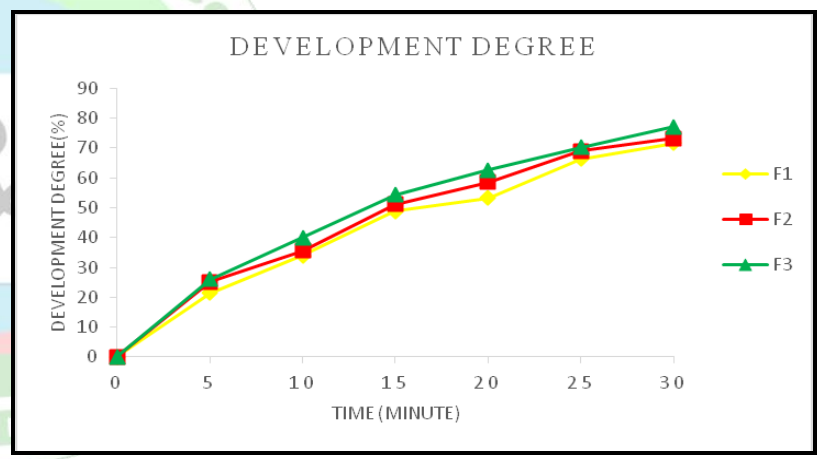

Figure: 1. Graph of patch development in phosphate buffer medium $\mathrm{pH}$ 7.4

The degree of development of each patch formula (figure 1) showed that from the three formulas the greatest degree of development results obtained from F3 containing $30 \%$ propylene glycol concentration followed by formulas $\mathrm{F} 2$ and $\mathrm{F} 1$. An increase in weight after soaking for some time in a phosphate buffer medium of pH 7.4 is due to water absorption. Propylene glycol is hygroscopic so that it can bind water together with increasing immersion time. Besides the composition in the patch there is also an HPMC polymer which one of the hydrophilic polymer parts, the characteristic of the hydrophilic polymer is its ability to expand to an unlimited degree when in contact with water and will quickly undergo dissolution ${ }^{21}$. Increase in the number of hydrophilic polymers in the preparation caused an increase in the absorption of water into the matrix which caused the formation of a gel layer in the hydrated layer, with an increase in the number of hydrophilic polymers in the matrix caused an increase in thickness of the gel layer. The formation of this gel will be a barrier and caused a decrease in the release of active substances through the matrix ${ }^{23}$. 


\section{Result of X-ray Diffraction (XRD)}

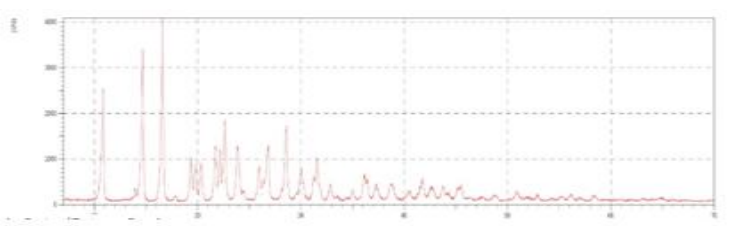

(A)

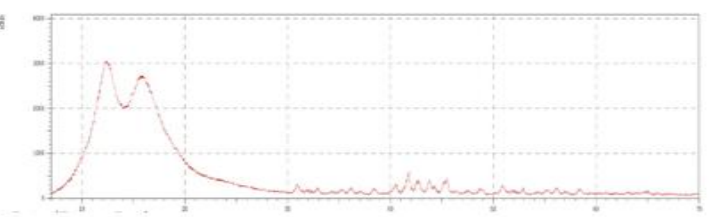

I

(B)
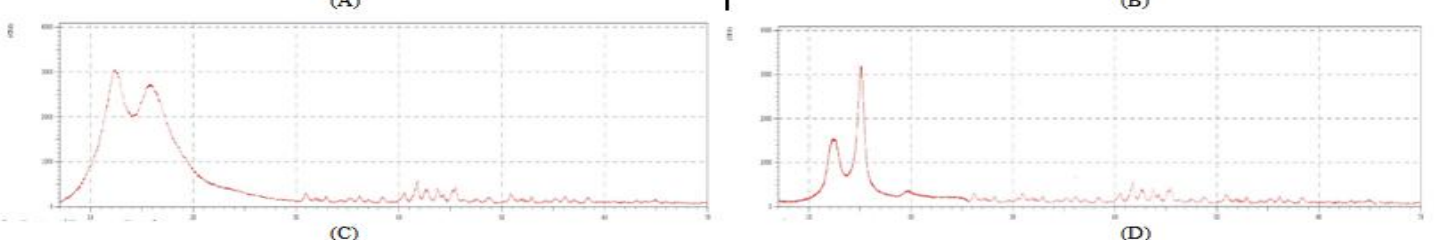

(C)

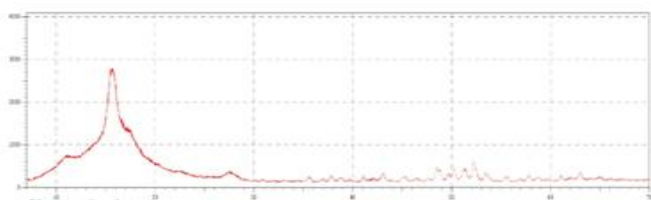

(E)

Figure: 2. Result of X-ray Diffraction (XRD)

Note: A: Ketoprofen XRD test results,B: PVP XRD test results,C: EC XRD test results,D: Ketoprofen mixtures in PVP polymers, HPMC and EC XRD test results

Ketoprofen X-ray diffraction shows the presence of 3 sharp-shaped peaks with high intensity at the peak regions of $10^{\circ}, 14^{\circ}$, and $17^{\circ}$ (Figure 2), and the lowest peaks shown at the peak regions of $54^{\circ}, 56^{\circ}, 57^{\circ}$. In ethyl cellulose (EC) polymers there are highest peaks at 5 $\circ$ and $12^{\circ}$. Polyvinylpyrrolidone (PVP) polymers have the highest peaks at $13^{\circ}$ and $16^{\circ}$. The hydroxypropyl methylcellulose polymer has the highest peaks at $12^{\circ}$ and $16^{\circ}$. Solid dispersion preparations have the highest peaks at $11^{\circ}$ and $15^{\circ}$ with a broad peak shape. In solid dispersion preparations the peak intensity decreases which is lower and wider than the standard form of ketoprofen. This shows that ketoprofen in the form of amorphous solid dispersion is compared to standard ketoprofen $^{24}$.

\section{Result of Spectra fourier-transform IR}

Testing using FTIR aims to determine the possibility of interaction between ketoprofen as an active ingredient with a polymer that is EC, HPMC, and PVP. The result could be seen on figure 3 .

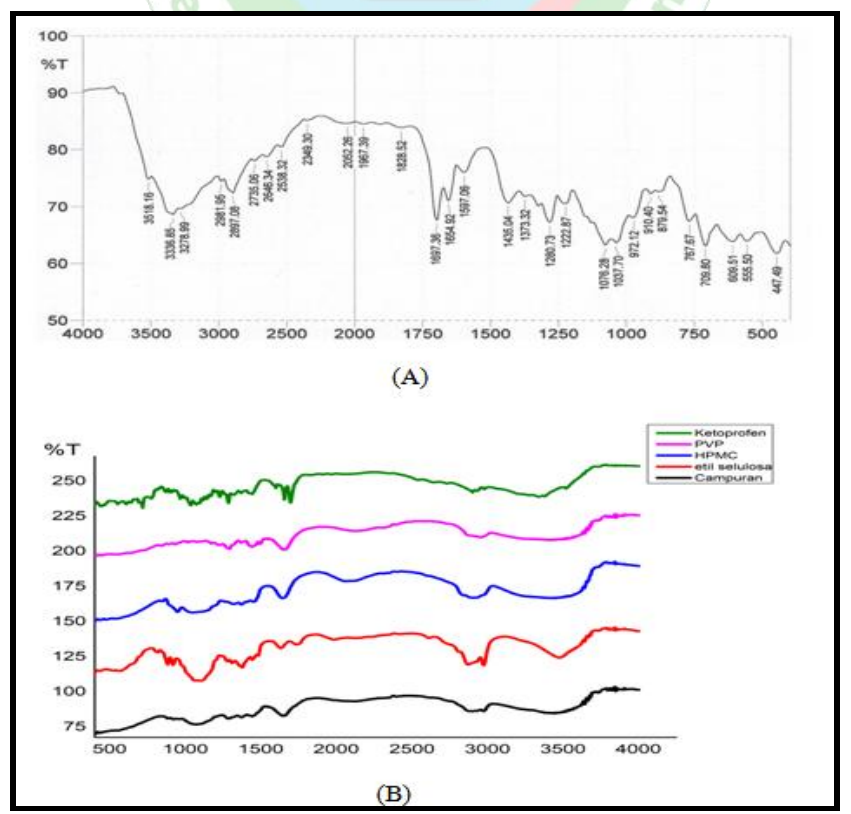

Figure: 3. Result of Spectra fourier-transform IR

Note: A: Ketoprofen FTIR test results,B: Ketoprofen, polymers and mixture FTIR test results

The results of the FTIR polymer test showed that the wavelength identified in the polymer was not the main wavelength of ketoprofen, so the use of EC, HPMC, and PVP bases did not affect the ketoprofen functional groups. These was consistent with research Zakir, et al. ${ }^{16}$ which states that the use of EC polymers, HPMC and
PVP is compatible or did not show any interaction with the active ingredient of ketoprofen.

\section{The Result of In Vitro Test}

Transdermal penetration test of ketoprofen solid dispersion patches 


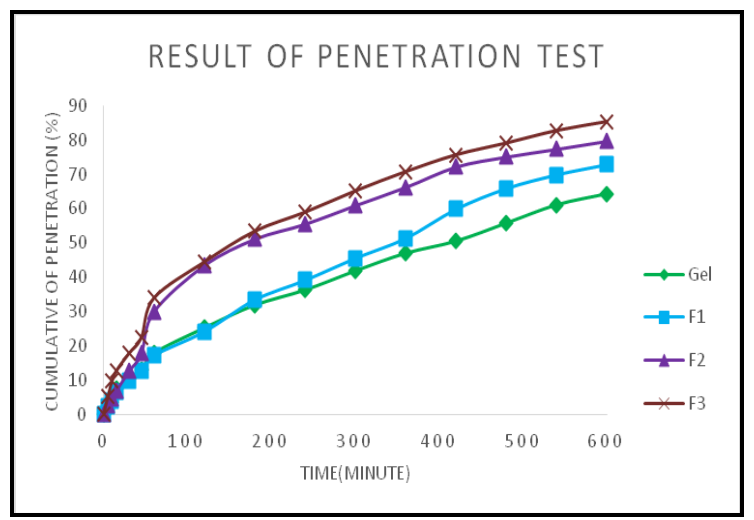

Figure: 4. Result of in vitro transdermal patch penetration test

Based on figure 4 above showed that the largest amount of penetration was formula 3 which containing propylene glycol by $30 \%$ with the amount of drug penetration by $85.34 \%$. Propylene glycol in the formula patch serves as an enhancer and plasticizer. Its mechanism of action as an enhancer is to increase the fluidity of the lipids so that the diffusion of the drug in the lipid bilayer will increase. Propylene glycol will dissolve polar groups in $\alpha$ keratin in the stratum corneum so that it will increase the distance to the lamellar which in turn will increase the drug partition in the stratum corneum ${ }^{25}$.

Ethyl cellulose is a neutral polymer that is hodrophobic, ethyl cellulose matrix will provide an obstacle to the penetration of liquid into the matrix, which causes the diffusion of the drug will be slow. PVP and HPMC polymers are hydrophilic polymers that can increase drug release, without the rate of controlling membrane hydrophilic polymers will release the drug quickly during dissolution testing ${ }^{26}$.

The EC-PVP-HPMC combination shows that trasdermal patch penetration can be controlled. EC serves to limit release by blocking the penetration of fluid into the matrix. PVP functions to form a pore that can increase the release of ketoprofen from its base. HPMC is a polymer that can swell (swellable) when in a suitable solvent ${ }^{21}$. Swellable polymers can increase tortuosity and diffusion of active ingredients resulting in faster drug release ${ }^{27}$.

From the results obtained, it could be concluded that the transdermal dense dispersion patch of ketoprofen (F3) had the highest amount of penetration compared to the transdermal dense dispersion patch F1, F2 and the trademark ketoprofen gel (Kaltrofen®).

\section{Determination of Optimum Formula}

Based on the results of characteristic tests (organoleptic, thickness, uniformity of weights, folding resistance and development) that all formulas meet the requirements to determine the highest penetration results to be selected for analgesic and anti-inflammatory testing. Based on the penetration test results above, it can be concluded that Formula 3 with propylene glycol concentration of $30 \%$ can penetrate $85.34 \%$. So that F3 was chosen for analgesic and anti-inflammatory testing.

\section{Result of Analgesic Effect}

The results of analgesic effect to determine the pain response time to infrared induction can be seen in Figure 5.

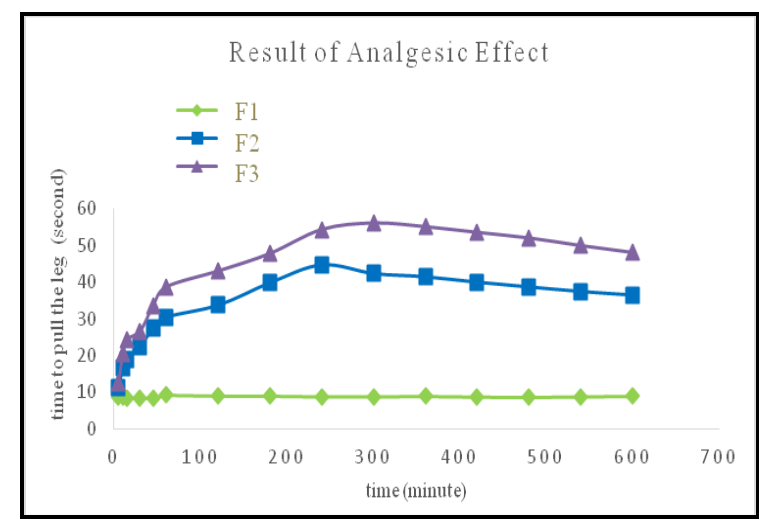

Figure: 6. The results of analgesic effect

F1: transdermal patch without medication (control),F2: trademark ketoprofen gel (Kaltrofen $囚), F 3$ : transdermal patch of ketoprofen (F3) solid dispersion

Based on the results of the analgesic test, the infrared plantar test method can be seen from the table and graph above that the longer the pain response time to infrared stimulation, the higher the analgesic effect. The trademark ketoprofen gel (Kaltrofen $®$ ) had the highest peak of analgesic effect in minutes to -240 which is 44.71 second. the time needed to hold pain induction for 600 minutes, the observation time showed that the control group did not show analgesic effects. The group that showed the highest analgesic effect seen from the graph is the transdermal patch of dense ketoprofen dispersion, kaltrofen® gel has a smaller analgesic effect.

The results of the analysis of variance showed that there were differences in the response of rats holding a significant induction of pain between treatment groups between the 5 th minute to the 600th minute. The average difference test $<0.05$ shows that there is a significant difference between the test group with the response time of mice to pain induction and vice versa average difference test> 0.05 shows there is no significant difference between the test group and the response time of mice to pain induction.

The Tukey test of the 5th to 600th minutes showed that there was a significant difference between the transdermal patch of the solid dispersion of ketoprofen and the trademark ketoprofen gel (Kaltrofen $®)$ and control.

From the results obtained, it could be concluded that the transdermal patch of the solid dispersion of ketoprofen had a better analgesic effect than the trademark ketoprofen gel (Kaltrofen®).

\section{Result of Anti-inflammatory effect}

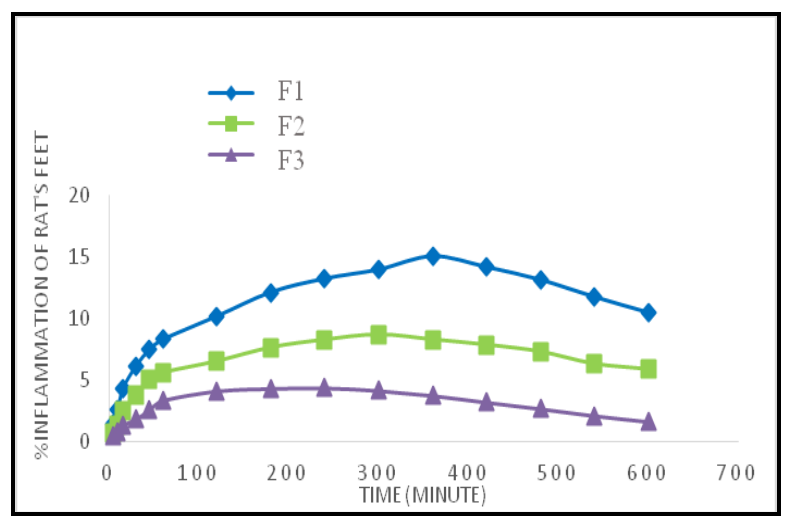

Figure 7. Result of antiinflammatory effect 
Note: F1: transdermal patch without medication (control), F2: trademark ketoprofen gel (Kaltrofen $\left.{ }^{\circledR}\right)$, F3: transdermal patch of ketoprofen (F3) solid dispersion

Figure 7 showed the highest average inflammation percentage is the control group, while the test group had an average inflammation percentage below the control group. The highest average percentage inflammation of the trademark ketoprofen gel group (Kaltrofen ${ }^{\circledR}$ ) was $8.69 \%$ in the 300th minute and started to decrease in the 360 th minute to the 600th minute to $5.89 \%$. The transdermal patch of ketoprofen solid dispersion patches had the highest average inflammation rate of $4.37 \%$ in the 240th minute and started to decrease in the 300th minute to the 600th minute to $1.61 \%$. The average inflammation percentage of the test group and the comparison drug group had an anti-inflammatory effect compared to the control group.

Inflammation produced by $\lambda$-carrageenan consists of two phases. The first phase, which is 1-2 hours after carrageenan injection, causes trauma due to inflammation caused by carrageenan. The trauma is caused by the release of histamine and serotonin from basophils and platelets to the site of inflammation. The second phase, which is 3-4 hours after carrageenan injection, releases prostaglandins from macrophages. The first phase is the beginning of an increase in inflammation and inflammation will occur in the second phase after carrageenan injection. If there is no inhibition of inflammation, the inflammation will be maintained until the 6th hour. Carrageenan produces inflammation that lasts for 6 hours and gradually decreases after 24 hours (Anwar, et al., 2013).

The percentage of inflammation inhibition indicates the ability of the test preparation to inhibit inflammation. In Figure 4.17 , it can be seen that the test material at the 5 th minute has had an effect. The results of calculating inflammation of the kaltrofen gel inflammation reached a maximum of $54.3 \%$. The transdermal patch group of ketoprofen solid dispersions gave a maximum inhibition of inflammation reaching $84.6 \%$.

\section{REFERENCES}

1. Adachi, Ioppolo L., Paoloni K., dan Santilli. Physical Characteristics, Pharmacological Properties and Clinical Efficacy of the Ketoprofen Patch: A New Patch Formulation. Eur Rev Med Phar Sci. 2011; 15: 823-830.

2. Vueba, J., Carvalho, V., Veiga, S.J., Sousa, R., dan Pina, S. Influence of Cellulose Ether Polymers on Ketoprofen Release from Hydrophilic Matrix Tablets. Internatioanal Journal of Pharmaceutical. 2004: 58: 51-59.

3. Shinkai, Korenaga, Mizu, dan Yamauchi. Intra-Articular Penetration of Ketoprofen and Analgesic Effects After Topical Patch Application in Rats. Journal Control Release. 2008; 131: 107-112.

4. Williams, A.C., dan Barry, B.W. Penetration Enhancers. Advanced Drug Delivery Reviews. 2004; 56: 603-618.

5. Ammar, H.O., M. Ghorabb, S. A., El-Nahhasa., dan Kamela, R. Evaluation of Chemical Penetration Enhancer for Transdermal Delivery of Aspirin. Asian Journal of Pharmaceutical sciences. 2007; 2 (3): 96-105.

6. Sharma, K., Mittal, A., dan Agrahari, P. Skin Permeation of Candesartan Cilexetil from Transdermal Patch Containing Aloe Vera Gel as Penetration Enhancer. Asian Journal of Pharmaceutics. 2013; 10 (2): 124.

7. Okyar, A., Ozsoy, Y., dan Gungor. Novel Formulation Approaches for Dermal and Transdermal Delivery of Non-Steroidal AntiInflamatory Drugs, Rhematoid Arthritis-Treatment. Europe: In Tech Europe. 2013. p. 102-106.

8. Venkatraman, S.N., Davar, A., Chester, dan Kleiner, L. An Overview of Controlled Release System. Handbook of

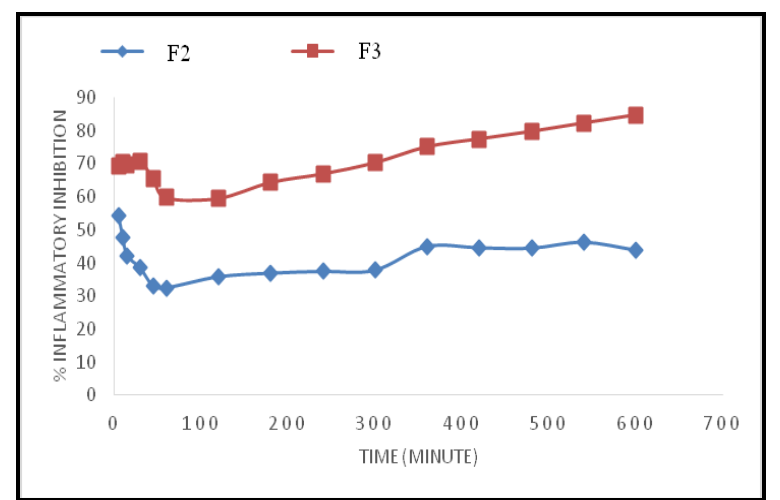

Figure 8. Percentage of inflammation inhibition

Note: F2: trademark ketoprofen gel (Kaltrofen®), F3: transdermal patch of ketoprofen (F3) solid dispersion

\section{CONCLUSION}

Based on the results of the study, it could be concluded that transdermal patches of ketoprofen solid dispersion patches produce white, odorless preparations that have a flat surface, thickness between $0.0242 \pm 0.0002$ to 0.0269 \pm 0.0003 , weight uniformity $321.50 \pm 0.78$ to $381.54 \pm$ 0.60 , folding resistance between $375 \pm 0.58$ to $443 \pm 1.53$, all formulas already meet the requirements of physicochemical characteristics. Based on the diffusion test results obtained the best penetration results are F3 which contains $30 \%$ PG, so it could be concluded that the use of propylene glycol affects the rate of drug release.

Transdermal patches of ketoprofen solid dispersions provide better analgesic effects compared to the trademark ketoprofen gel (Kaltrofen $®)$, and there are significant differences between groups. Transdermal patches of ketoprofen solid dispersion patches had a better anti-inflammatory effect compared to the trademark ketoprofen gel (Kaltrofen $®)$, and there were a significant differences between groups.

\section{CONFLICT OF INTERESTS}

All author have no to declare.

Pharmaceutical Controlled Release Technology. New York: Marcell Dekker, Inc. 2002. p.48-60.

9. Prabhakar, D.J., Sreekanth, dan Jayaveera, K.N. Transdermal Drug Delivery Patch: A Review. Journal of Drug Delivery and Therapeutics. 2013; 3 (4): 213-221.

10. Nurahmanto, D., Sabrina, F.W., dan Ameliana, L. Optimasi Polivinilpirolidon dan Carbopol Pada Sediaan Patch Dispersi Padat Piroksikam. Skripsi. Fakultas Farmasi Universitas Jember. 2017. p. 27.

11. Wen, H., dan Park, K.. Oral controlled release formulation design and drug delivery. Theory to practice. New Jersey: John Wiley \& Sons, Inc. 2010. p.113.

12. Bharkatiya, M.R.K., Nema, M., dan Bhatnagar. Development and Characterization of Transdermal Patches of Metoprolol Tartrate. Asian Journal of Pharmaceutical and Clinical Research. 2010; 3 (2): 130-134.

13. Kandavili, S., Nair, V., dan Panchagnula, R. Polymers in Transdermal Drug Delivery Systems. Pharmaceutical Technology and Research. 2002; 62-80.

14. Sweetman, S.C. Martindale: The Complete Drug Refrence. Thirtysixth Edition. London: Pharmaceutical Press. 2009. p.782-811.

15. Bhowmik, D., Duraivel, G.H.S., Kumar, B.P., Raghuvanshi, V., dan Kumar., K.P. S. Solid Dispersion-A Approach To Enhance The Dissolution Rate of Poorly Water Soluble Drugs.The Pharma Innovation-Journal. 2013; 1 (12): 24-38.

16. Zakir, S., Banu, S.K., Fatima, S.N., Jahan, T., Firdous, W., Sireesha, Roshan, S., dan Mahammed, N.L. Formulation and Evaluation of Transdermal Patchs of Ketoprofen by Using Different Polymers. International Journal Pharmaceutical Science. 2015; 3 (4): 989-996. 
17. Newa, M., Bhandari, K.H., Kim, O.J., Im, S.J., Kim, J.A., dan Yoo, B.K. Preparation and Evaluation of Immediate Release Ibuprofen Solid Dispersion Using Polyethylene Glycol 4000. Biol.Pharm.Bull. 2008; 31 (5): 939-945.

18. Akhtar, N., Rehman, M.U., Khan, H.M.S., Rasool, F., Saeed, T., dan Murtaza, G. Penetration Enhancing Effect of Polysorbate 20 and 80 on the In Vitro Percutaneous Absorption of L-Ascorbic Acid. Tropical Journal of Pharmaceutical Research. 2011; 10 (3) 281-288.

19. Ramkanth, S., Jayaprakash, S., dan Vimalakanan, T. Formulation and Evaluation of A Monolithic drug-In-Adhesive Type Patch Containing Tenoxicam. International Journal of Pharma Sciences and Research (IJPSR). 2015; 6 (4): 9475-9492.

20. Tyagi, S., dan Goyal, K.. Transdermal Drug Delivery System: Quality Approaches And Evaluation. Innovat International Journal Of Medical \& Pharmaceutical Sciences. 2017; 2 (3): 15-21.

21. Rowe, R.C., Sheskey, P.J., dan Quinn, M.E.. Handbook of Pharmaceutical Exipients. Edisi keenam. London: Pharmaceutical Press and American Pharmacists Assosiation. 2009. p. 257, 273, 413.

22. Jhawat, C.V., Saini, S. Kamboj, dan Maggon, N. Transdermal Drug Delivery System: Approaches and Advancements in Drug Absorption Through Skin. International Journal of Pharmaceutical Sciences and Research. 2013; 47-56.
23. Chandra, Ramesh, Vamshi, Kishan, dan Madhsudan. Development of Mucoadhesive Patches for Buccal Administration of Prochlorperazine: Evaluation of In Vitro Release and Mechanical Properties. International Journal of Pharmaceutical Sciences and Nanotechnology. 2008; 1: 64-70.

24. Zaini, E., Sumirtapura, Y. C., Soewandhi, S. N., dan Halim, A. Identifikasi Interaksi Fisika antara Trimetoprim dan Sulfametoksazole dengan Metode Kontak Kofler dan reaksi kristalisasi. Majalah Farmasi Indonesia. 2010; 21(1):32-39.

25. Benson, H.A.E., dan Watkinson, A.C. Topical and Transdermal Drug Delivery: Principles and Practice. A John Wiley \& Sons inc. Publication. 2012. p. 85-89.

26. Chauhan, S., Bolmal, U.D., Dandagi, P.M., dan Singh, A. Design and Evaluation of Transdermal Patch of Felodipine. Indo American Journal of Pharmaceutical Research. 2015; 5(09): 2231-6876.

27. Kumar, S., Tarun, P., dan Kumar, T. Transdermal Drug Delivery System for Non-Steroidal Anti-Imflammatory Drug: A Review. Journal of Control Release. 2013; 3588-3605.

28. Anwar, K., Santoso, H.B., dan Cahaya, N. (2013). Penghambatan Radang Infusa Daun Dadap Ayam (Erythrina variegata L.) Pada Mencit Jantan yang di induksi Karagenin. Prosiding Semirata FMIPA Universitas Lampung. 2013. p.73. 